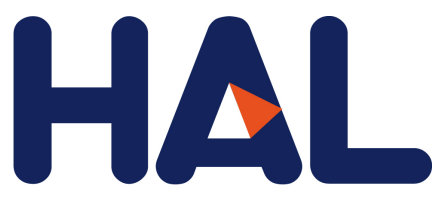

archives-ouvertes

\title{
A chironomid-inferred Holocene temperature record from a shallow Canadian boreal lake: potentials and pitfalls
}

Lisa Bajolle, Isabelle Larocque-Tobler, Adam Ali, Martin Lavoie, Yves Bergeron, Emmanuel Gandouin

\section{To cite this version:}

Lisa Bajolle, Isabelle Larocque-Tobler, Adam Ali, Martin Lavoie, Yves Bergeron, et al.. A chironomidinferred Holocene temperature record from a shallow Canadian boreal lake: potentials and pitfalls. Journal of Paleolimnology, Springer Verlag, In press, $<10.1007 /$ s10933-018-0045-9 > $<$ hal-01890717>

\section{HAL Id: hal-01890717 \\ https://hal-amu.archives-ouvertes.fr/hal-01890717}

Submitted on 15 Oct 2018

HAL is a multi-disciplinary open access archive for the deposit and dissemination of scientific research documents, whether they are published or not. The documents may come from teaching and research institutions in France or abroad, or from public or private research centers.
L'archive ouverte pluridisciplinaire HAL, est destinée au dépôt et à la diffusion de documents scientifiques de niveau recherche, publiés ou non, émanant des établissements d'enseignement et de recherche français ou étrangers, des laboratoires publics ou privés. 
A chironomid-inferred Holocene temperature record from a shallow Canadian boreal lake: potentials and pitfalls

LISA BAJOLLE ${ }^{1.2}$. ISABELLE LAROCQUE-TOBLER ${ }^{3}$. ADAM A. ALI ${ }^{1.2}$. MARTIN LAVOIE ${ }^{4}$. YVES BERGERON ${ }^{1.5}$. and EMMANUEL GANDOUIN ${ }^{6}$

${ }_{(}^{1}$ Institut de Recherche sur la forêt. Université du Québec en Abitibi-Témiscamingue. RouynNoranda. QC. Canada; ${ }^{2}$ Institut des Sciences de l'Évolution-Montpellier. UMR 5554. Université de Montpellier CNRS-IRD-EPHE. Montpellier. France ${ }^{3}$ The L.A.K.E.S Institute. Lyss. Switzerland; ${ }^{4}$ Département de géographie and Centre d'études nordiques. Université Laval. Québec. QC. Canada); ${ }^{5}$ Centre d'Étude de la Forêt. Université du Québec à Montréal. Montréal. QC. Canada; ${ }^{6}$ Aix Marseille Univ. Avignon Université. CNRS. IRD. IMBE. Aix en Provence. France 


\begin{abstract}
The biodiversity of shallow $\left(\mathrm{z}_{\max }<5-7 \mathrm{~m}\right)$ lakes is sensitive to water-level and climate changes, but few such aquatic ecosystems have been studied in the context of quantitative climate reconstruction. Lac Lili (unofficial name) is located in the boreal forest of western Quebec, Canada, and was chosen for its shallowness $\left(\mathrm{z}_{\max }=1.40 \mathrm{~m}\right)$ to assess if chironomid assemblages in the sediments could be used to reconstruct Holocene temperature fluctuations quantitatively. Inferred temperatures displayed a decreasing trend from a maximum value ca. 8000-3500 cal year BP, slight warming between ca. 3500 and 3000 cal year BP, followed by cooling to the present. Although chironomid assemblages were influenced by factors other than climate, primarily water depth and changes in macrophyte richness, the reconstructed Holocene temperature pattern was very similar to the known regional climate history. Temperature inferences derived from the chironomid assemblages were, however, warmer than the two reference periods. This deviation was likely a consequence of three factors: (1) shallowness of the lake, which favoured littoral taxa with warmer-than-today temperature optima, (2) the low number of lakes warmer than $16^{\circ} \mathrm{C}$ in the training set, and (3) the absence of shallow lakes in the training set.
\end{abstract}

Keywords Chironomidae. Holocene. Paleoclimate reconstructions. Transfer function. Water level. Boreal forest 


\section{Introduction}

Ponds and shallow lakes $\left[\mathrm{Z}_{\max }<5-7 \mathrm{~m}\right.$, and with light penetration to the bottom (Wetzel 2001)] are the most abundant water bodies in the world (Meerhoff and Jeppesen 2009) and they are particularly sensitive to water-level fluctuations and climate changes (Jeppesen et al. 2014; Smol 2016). Water level fluctuations between extreme highs and lows may cause shifts between turbid and clear-water, macrophyte-dominated states (Coops et al. 2003), thus affecting the biota and the lake's ecological functions. Submerged macrophytes play an important role in these lakes, as they influence oxygen conditions and inhibit the resuspension of sediments, which may possibly reduce phytoplankton biomass (Blindow et al. 2002). Shallow eutrophic lakes can develop in two states of equilibria: a clear-water state characterized by high water transparency and abundant submerged vegetation, and a turbid state characterized by high phytoplankton densities and low transparency. A shift from one state to the other can result from water-level changes (Blindow et al. 2002; Scheffer and van Nes 2007; Tarkowska-Kukuryk and Kornijów 2008). Climate projections for the eastern Canada Boreal Shield display an increase in annual mean temperature by 2100 , ranging up to $5^{\circ} \mathrm{C}$ in summer, as well as an increase of $13 \%$ in annual precipitation, mainly in winter and spring. with less in summer (Price et al. 2013). Consequently, Mooij et al. (2007) suggested that this change in climate will enhance external nutrient loading, possibly causing a shift from a clear to a turbid state in lacustrine ecosystems. These predictions, however, lack long-term data to study the dynamics among climate (temperature and precipitation) changes, water-level fluctuations, and biotic changes, notably in shallow lakes.

Long-term relationships between shallow lake ecological functions and climate can be obtained from chironomids preserved in lake sediments (Smol 2016). Chironomid (non-biting midges) head capsules are made of chitin that can be preserved for up to 200,000 years (Axford 
et al. 2009), and have been used to reconstruct air temperature quantitatively in many areas of the world (Brooks and Birks 2001; Walker and Cwynar 2006; Heiri et al. 2007; Millet et al. 2012), sometimes with high accuracy (difference between instrumental and inferred data $=$ $0.8^{\circ} \mathrm{C}$ on average) (Larocque and Hall 2003; Larocque et al. 2009; Larocque-Tobler et al. 2016; Luoto and Ojala 2017; Zhang et al. 2017). Although the technique can provide accurate results, most of the studied lakes were deep. To our knowledge. quantitative temperature reconstructions using chironomid head capsules have never been conducted in shallow lakes in Eastern Canada and were attempted in only one shallow (depth $<5 \mathrm{~m}$ ) lake in Western Canada (Upiter et al. 2014).

In shallow [<5-7 m (Wetzel 2001)] lakes, chironomid assemblages are composed mainly of littoral taxa influenced primarily by water-level changes (Engels and Cwynar 2011; Engels et al. 2012), turbidity (Greffard et al. 2012), macrophyte species richness (Langdon et al. 2010), and total phosphorus (Brodersen and Lindegaard 1997). Temperature is also an important factor that influences chironomid communities in shallow lakes, but as such communities are composed of littoral taxa, which tend to have warm optima (Korhola et al. 2002), reconstructions based on these assemblages might yield warmer inferences than would otherwise be expected. Nevertheless, because shallow lakes are very sensitive to temperature and precipitation, climate reconstructions from these ecosystems might be valuable.

Our study site is located in western Quebec (Fig. 1), 110 km north of the town of RouynNoranda. "Lac Lili” (Unofficial name: 49²10'25.501"N; 79²2'26.931"O, $320 \mathrm{~m}$ a.s.1.) is a shallow lake $\left(\mathrm{z}_{\max }=1.40 \mathrm{~m}\right)$ that covers an area of 10 ha and lacks both inlets and outlets. It is located in the black spruce-feather moss bioclimatic domain (Saucier et al. 2009). Forest cover is dominated by trembling aspen (Populus tremuloides), black spruce (Picea mariana Mill.). and jack pine (Pinus banksiana Lamb) (Blouin and Berger 2005). The mean annual temperature recorded at the closest meteorological station [La Sarre: 1961-1990] is $0.8{ }^{\circ} \mathrm{C}$, 
with August temperature averages of $15.0^{\circ} \mathrm{C}(1961-1990)$ and $15.4^{\circ} \mathrm{C}(1981-2010)$. Mean annual precipitation is $640 \mathrm{~mm}$, of which $250 \mathrm{~mm}$ falls as snow (Environnement Canada 2016).

Lac Lili is located $395 \mathrm{~km}$ from Lac Aurélie (49¹0'25.501"N; 79²2'26.931"W; black spruce-feather moss bioclimatic domain; $320 \mathrm{~m}$ a.s.1; 1 ha. $10 \mathrm{~m}$ deep) (Fig. 1), where a chironomid-inferred temperature reconstruction was carried out and was similar to regional and hemispheric temperature records (Bajolle et al. 2018). Multi-site comparison [Lac Lili versus Lac Aurélie (Bajolle et al. 2018)] will place the climate reconstruction within a regional context. If the patterns are similar at both sites, it will provide support for regional climate change having been reconstructed accurately, whereas if they diverge. the differences might be a consequence of local effects (e.g. water-level fluctuations. fire regime). The goal of this study was to assess if chironomid assemblages from a shallow lake can be used to infer air temperature quantitatively and reconstruct the general pattern of climate change in this region.

\section{Materials and methods}

Coring, stratigraphy, chronology

Two overlapping sediment cores were taken in March 2014 through the frozen surface at the centre of Lac Lili using a modified Livingstone-type square-rod piston corer $(100 \times 5 \mathrm{~cm})$. The water-sediment interface was collected using a Kajak-Brinkhurst (KB) gravity corer (Glew 1991). The extruded cores (310 and $306 \mathrm{~cm}$ long) were sectioned into $0.5-\mathrm{cm}$ intervals to achieve high-temporal sampling resolution. Terrestrial plant macrofossils (seeds, needles and bark) were retrieved from seven samples for AMS radiocarbon dating (Table 1). The ${ }^{14} \mathrm{C}$ dates were calibrated at $2 \sigma$ ranges using the Clam package (Blaauw 2010) of R software version 3.0.1 (R Core Team 2016) based on the non-marine (IntCal13) radiocarbon calibration curve 
(Hua et al. 2013; Reimer et al. 2013). The age-depth model (Fig. 2) was obtained using a 'classical' age-depth model with a smoothing spline function (Blaauw 2010). All dates are expressed in calibrated years before present, hereafter cal year BP.

Chironomid analyses

Sediment slices of $0.5 \mathrm{~cm}$ were sampled at intervals varying between 4,2 , and $1 \mathrm{~cm}$, for a total of 116 samples. Samples were soaked overnight in $10 \% \mathrm{KOH}$ and then rinsed with water and filtered through a $100-\mu \mathrm{m}$ mesh. The remains were poured into a counting tray and observed under a stereomicroscope at 10× magnification. Each head capsule (whole and half mentum) was individually picked with fine tweezers and mounted on a microscope slide in a drop of glycerine. Slides were observed under a light microscope at 400-1000× magnification following the taxonomic guide of Brooks et al. (2007). A minimum of 50 head capsules is needed for temperature reconstructions (Larocque 2001; Heiri and Lotter 2010). All samples in this study contained at least 92 head capsules.

A chironomid stratigraphy (percentage of each taxon in each sample) was constructed using C2 software (Juggins 2003). Only taxa present in more than six samples are shown in Fig. 3. A detrended correspondence analysis (DCA) was performed on a matrix of square-roottransformed percentages using ade4 and vegan packages from the R v3.2.2 software package (Borcard et al. 2011). The length of the DCA-axis shows whether or not the distribution of the data set along the axis is linear or unimodal (Borcard et al. 2011). A PCA calculated with C2 software was used to study the changes in chironomid assemblages through time on a dispersion matrix of square-root-transformed percentages into which rare taxa with abundances $<1 \%$ in fewer than two samples were removed. A constrained sum-of-squares cluster analysis (CONISS; Grimm 1987) was used to identify zones in the stratigraphy. with the significance 
of each zone tested with the broken stick model (Bennett 1996) using the Rioja R package (Juggins et al. 2015). Percentages of littoral and eutrophic taxa were determined (Table 2) based on Brooks et al. (2007).

Temperature reconstruction

A new Eastern Canadian model, modified from Larocque et al. (2006) and Larocque (2008), and utilized for climate reconstruction at Lac Aurélie (Bajolle et al. 2018), was used. The training set comprises 75 lakes (no outliers) and 79 taxa with abundances of $>1 \%$ in more than two lakes. Mean August temperature varied from 3 to $21^{\circ} \mathrm{C}$ for a temperature gradient of $18^{\circ} \mathrm{C}$. WAPLS 999-bootstrap with two components yielded a correlation coefficient $\left(r^{2}\right.$ boot $)$ of 0.85 , an RMSEP of $1.67^{\circ} \mathrm{C}$ and a maximum bias of $3.05^{\circ} \mathrm{C}$. Occurrence of taxa and temperature optima can be found in Bajolle et al. (2018) and in Table 2. Sample specific errors (eSEP) were calculated. To validate the use of the transfer function. an evaluation of modern analogues for each sample was performed using the minimum distance of the fossil sample to the training set assemblages (Overpeck et al. 1985). Fossil samples with a distance above the $20^{\text {th }}$ percentile were considered as having "no analogues", and those above the $10^{\text {th }}$ were considered to be "poor analogues" (Overpeck et al. 1985). Percentages of taxa colder or warmer than $13.6^{\circ} \mathrm{C}$ (average of temperature optima of taxa found in Lac Lili) were calculated using the temperature optima obtained from the transfer function (Table 2). This site-specific cut-off is not far from the average temperature optima of the 79 taxa found in the training set $\left(13.2^{\circ} \mathrm{C}\right)$. The difference between average temperature inferences and reference values (climate normals: 1961-1990 and 1981-2010) was performed using a t-test. 


\section{Results}

Chronology and sedimentation rates

The core was $310 \mathrm{~cm}$ long and composed entirely of gyttja. An age of ca. 8407-8522 cal year BP (2 sigma range) was obtained at the bottom of the core $(304-306 \mathrm{~cm})$ (Table 1). Three periods were identified with respect to sedimentation rates, based on the age-depth model (Fig. 2). Period 1 (ca. $8600-3500$ cal year BP; $310-180 \mathrm{~cm}$ ) showed a low sedimentation rate (mean: $0.04 \mathrm{~cm} / \mathrm{yr}$ ). During Period 2 (ca. 3500-2700 cal year BP; 180-120 cm), the average sedimentation rate increased quickly to $0.09 \mathrm{~cm} / \mathrm{yr}$. Period 3 (ca. $2700 \mathrm{cal}$ yr BP to Present; $120-0 \mathrm{~cm}$ ) was characterized by a decrease in sedimentation rate (mean: $0.02 \mathrm{~cm} /$ year).

Chironomid stratigraphy

In total, 116 samples were analysed. with a total of 11,693 head capsules (hereafter HC) identified. All samples had more than $92 \mathrm{HC}$, with an average of $100 \mathrm{HC}$ per sample (Fig. 3). Fifty-eight taxa were identified and 42 of them are presented in Fig. 3. The 16 taxa not illustrated occurred in $<6$ samples at percentages $<1.9 \%$, thus did not contribute much to the temperature reconstruction (Table 2).

The chironomid stratigraphy was divided into four statistically significant zones (Lch1 to Lch-4; Fig. 3). In general, both littoral and warmer-than $-13.6^{\circ} \mathrm{C}$ taxa dominated the chironomid community throughout the core, with average percentages of $80 \%$ and $66 \%$. Respectively, whereas colder-than- $13.6^{\circ} \mathrm{C}$ taxa had percentages that ranged between 13 and $50 \%$ (average: $34 \%$ ). 
DCA yielded a gradient of 1.6 SD, suggesting that linear regression such as PCA was appropriate. PCA Axis 1 and had eigenvalues of 0.18 and 0.12 , respectively.

During zone Lch-1 (ca. 8500-5700 cal year BP; 310-240 cm), littoral taxa were below average and increased after 6300 cal year BP. Eutrophic taxa oscillated around the average. PCA Axis 1 scores were above 0, whereas PCA Axis 2 scores were generally below 0 . The dominant taxa were Tanytarsus glabrescens-type, Procladius spp., Ablabesmyia spp., Polypedilum nubeculosum-type, Tanytarsus pallidicornis-type, Lauterborniella spp., Dicrotendipes nervosus-type and Tanytarsus mendax-type. Cladotanytarsus mancus-type and Psectrocladius sordidellus-type percentages increased towards the end of the zone. Pagastiella spp. and Allopsectrocladius spp. had their highest percentages of the record. Taxa with warmerthan $-13.6^{\circ} \mathrm{C}$ optima dominated the assemblages, with percentages $>68 \%$.

In zone Lch-2 (ca. 5700-3500 cal year BP; 240-180 cm), percentages of colder-than$13.6^{\circ} \mathrm{C}$ taxa increased above average $(32 \%)$, while warmer-than- $13.6^{\circ} \mathrm{C}$ taxa decreased below average. but always remained higher than $48 \%$. PCA Axis 1 scores decreased compared to the previous zone, but remained slightly above 0 , whereas PCA Axis 2 scores were mainly above 0. Eutrophic taxa percentages were above average until ca. 5000 cal year BP, then decreased below average until the end of the zone. Percentages of littoral taxa started below average until ca. 5000 cal year BP but increased until the end of the zone. The dominant taxa were the same as in the previous zone, however Paratanytarsus spp. started to be recorded consistently and Tanytarsus spp. increased towards the end of the zone. Stempellinella had higher percentages at the beginning of the zone than in the previous section. but it decreased and occasionally disappeared after ca. 5000 cal yr BP.

In zone Lch-3 (ca. 3500-1200 cal year BP; $180-55 \mathrm{~cm}$ ), the percentages of littoral taxa fluctuated around the average. Eutrophic taxa percentages started well above average. decreased. and then finally increased again after 2000 cal year BP. PCA Axis 1 scores 
decreased below 0 and PCA Axis 2 scores remained above 0 , with a tendency to decrease to the end of the zone. T. glabrescens-type percentages decreased sharply compared to zone Lch2. Microtendipes pedellus-type, Chironomus anthracinus-type and Guttipelopia spp. were recorded consistently. Stempellinella spp. and Stempellina spp. had higher percentages at the beginning of the zone and then decreased thereafter. Warmer-than- $13.6^{\circ} \mathrm{C}$ and colder-than$13.6^{\circ} \mathrm{C}$ taxa percentages oscillated around their averages.

Zone Lch-4 (ca. 1200 cal year BP to present; $55-0 \mathrm{~cm}$ ) had increases in the percentages of $P$. septentrionalis-type, P. sordidellus-type, M. pedellus-type, Paratanytarsus spp., T. pallidicornis-type, T. mendax-type and a slight increase in T. glabrescens-type. Ablabesmyia spp. was also recorded more regularly. PCA Axis 1 and Axis 2 scores were below 0. The percentages of eutrophic taxa decreased below average while littoral taxa oscillated. Percentages of colder-than-today taxa were above average (32-50\%) whereas warmer-than$13.6^{\circ} \mathrm{C}$ were below average, but percentages remained higher than $48 \%$.

Temperature reconstructions

Eight of the 116 fossil samples had no modern analogues (Fig. 4a) and 85 samples had poor analogues compared to the training set samples. During zone Lch-1 (8500-5800 cal year BP). the average reconstructed temperature was $16.9^{\circ} \mathrm{C}$, with a decrease from $19^{\circ} \mathrm{C}$ (maximum) to $17^{\circ} \mathrm{C}$ at the end of the zone. In zone Lch-2 (ca. 5700-3500 cal year BP), temperatures had an average of $16.8^{\circ} \mathrm{C}$, with a decrease from $17.8^{\circ} \mathrm{C}$ around $5200 \mathrm{cal}$ year $\mathrm{BP}$ to $16.2^{\circ} \mathrm{C}$ at $3400 \mathrm{cal}$ year BP. Zone Lch-3 (ca. 3500-1200 cal year BP) started with inferences for high temperatures $\left(19.3-18.5^{\circ} \mathrm{C}\right)$, followed by a decrease to $16.8^{\circ} \mathrm{C}$ between ca. 3000 and 2500 cal year BP. An increase $\left(18.3\right.$ and $\left.19.6^{\circ} \mathrm{C}\right)$ was inferred for the period between 1800 and 1500 cal year BP. The average chironomid-inferred temperature during Zone 3 was $17.9^{\circ} \mathrm{C}$. In the last zone (Lch- 
4), the temperatures decreased from ca. $17.5^{\circ} \mathrm{C}$ at the beginning of the zone to $14.8^{\circ} \mathrm{C}$ at the end of the zone. The average during this zone was $16.5^{\circ} \mathrm{C}$.

The temperature anomalies show that throughout the whole record. only six of the inferences were colder than the climate normal of $15.4^{\circ} \mathrm{C}$ and three were colder than today. with the climate normal of $15^{\circ} \mathrm{C}(\mathrm{Fig} .4 \mathrm{~b})$. The average anomaly from $15^{\circ} \mathrm{C}\left(2.10^{\circ} \mathrm{C}\right)$ and from $15.4^{\circ} \mathrm{C}\left(1.70^{\circ} \mathrm{C}\right)$ for the whole record showed that the temperature inferences were generally and significantly $\left(p<2.210^{-16}\right)$, warmer than today.

\section{Discussion}

Chironomid assemblages

As expected for a shallow lake, the chironomid assemblages were dominated by littoral and eutrophic taxa, which tend to have warmer optima (Table 2) and are generally influenced by water levels (Engels and Cwynar 2011; Engels et al. 2012), turbidity (Greffard et al. 2012), macrophyte species richness and abundance (Langdon et al. 2010), and total phosphorus (Brodersen and Lindegaard 1997). In Lac Lili, when the PCA Axis 1 scores decreased below 0, the sum of Chironomini increased (Fig. 5). Korhola et al. (2002) also observed that chironomids with warm temperature optima dominated assemblages in a shallow lake in Finland, and high sums of Chironomini have been linked to water levels and macrophyte species richness and abundance (Langdon et al. 2010). Thus, water levels and macrophytes were possibly the main factors that drove chironomid assemblages in Lac Lili.

The main changes occurred ca. 3500 cal year BP when PCA axis 1 scores changed from positive to negative. Before ca. 3500 cal year BP, the assemblages were dominated by Tanytarsus glabrescens-type and were replaced by Polypedilum nubeculosum-type and 
Microtendipes pedellus-type, which are often associated with floating-leaved plants and other macrophytes (Learner et al. 1989; Tarkowska-Kukuryk and Kornijów 2008). Synchronously Tanytarsini-dominated communities shifted to Chironomini-dominated assemblages (Fig. 5), possibly with a change in water level (shallowing) and macrophyte species richness and abundance (Langdon et al. 2010), as illustrated by the strong increase in Nuphar (a floatingleaved plant) pollen in Lac Lili (Fig. 5). The timing of this major change in the chironomid assemblages coincides with the start of the Neoglacial, when climate became wetter in this region (Garralla and Gajewski 1992; Viau and Gajewski 2009; Hély et al. 2010; Ali et al. 2012; El-Guellab et al. 2015).

After 1500 cal year BP, the percentages of both Psectrocladius types and Cricotopus spp. largely increased along with Pentaneurini spp. and Ablabesmyia spp. Psectrocladius is often associated with macrophytes (Brodersen et al. 2001; Langdon et al. 2008). Cricotopus. Ablabesmyia and Zalutschia spp. are associated with vegetation (Brooks et al. 2007). Although Chironomini still dominated, they started to decrease, while Tanytarsini started to increase. This change suggests the onset of a new state, perhaps as a response to colder conditions, as suggested by the decrease in taxa with optima warmer than $13.6^{\circ} \mathrm{C}$.

Comparison with other regional climate records

PCA axis 1 seems to be related with warmer-than- $13.6{ }^{\circ} \mathrm{C}$ taxa, but not directly to inferred temperature, suggesting that confounding factors (eutrophication, water-level changes and macrophytes) impacted the chironomid assemblages more than temperature. Nevertheless, the general pattern of temperature changes (i.e. warm middle Holocene to ca. 3500 cal year BP, with a decreasing trend to the present) reconstructed using the chironomids follows the quantitative paleoclimatic reconstructions based on the chironomid record of Lac Aurélie (Fig. 
5) and pollen from the Province of Quebec (Viau et al. 2006). A Neoglacial period with cooler conditions started at 3500 cal year BP in this region (Garralla and Gajewski 1992; Viau and Gajewski 2009; Ali et al. 2009; Hély et al. 2010).

The PCA axis 2 scores showed their main changes between ca. 3500 and 3000 cal year BP when chironomid-inferred temperatures were warmer and eutrophic percentages increased. The sedimentation rates during that period also increased (Period 2; Fig. 2). Major changes in sedimentation rates at that time were also recorded by Ali et al. (2008) in western Québec and were interpreted as having been caused by a major flood in the watershed between ca. 3600 and 1900 cal year BP, causing a rapid rise in lake level. Consequently, the increase in sedimentation rate is possibly associated with an increase in precipitation, as suggested by the changes in the chironomid assemblages that show highest percentages of eutrophic taxa. A similar warming $\left(\sim 1^{\circ} \mathrm{C}\right)$ period was also reconstructed using chironomids at Lac Aurélie (Fig. 5) and in the pollen record of Viau and Gajewski (2009), but at lower amplitude. The agreement between our results and other regional records suggests that although temperature was not the only factor that affected chironomid assemblages, patterns of climate change could still be adequately reconstructed.

Quantitative temperature reconstruction in a shallow boreal lake

The temperature pattern through the Holocene was similar to that in other regional records. The goal of using quantitative methods to reconstruct climate, however, is to obtain accurate inferences, not only a pattern of change. Reconstruction of climate from chironomid assemblages in a shallow study lake may compromise its accuracy. For instance. most inferences were warmer by 1.7 to $2^{\circ} \mathrm{C}$ than the climate normals $\left(1981-2010,15.4^{\circ} \mathrm{C}: 1961-\right.$ 1990, $15^{\circ} \mathrm{C}$ ) (Fig. 4). This was not the case for the chironomid-inferred reconstruction in Lac 
Aurélie or in pollen records of the region (Viau and Gajewski 2009). which all show periods with colder-than-the-climate normal inferences. Twenty-seven of the taxa have temperature optima warmer-than- $13.6^{\circ} \mathrm{C}$ and nine of fourteen taxa with percentages reaching $20 \%$ or higher have warmer-than- $13.6^{\circ} \mathrm{C}$ optima (Fig. 3). Thirteen taxa have temperature optima between 14.9 and $25.3^{\circ} \mathrm{C}$. Three of them have percentages of $20 \%$ or more and temperature optima between 15.8 and $25.3^{\circ} \mathrm{C}$. When using WAPLS. these taxa contribute more to the temperature inference and thus lead to temperature inferences well above the climate normal.

This lower accuracy can potentially be explained by a few factors: (1) littoral taxa dominate the assemblages (average $=80 \%$ ), (2) warm-optimum taxa also dominate (average $=66 \%$ ), (3) the training set has only 11 lakes with mean August temperature above $15.8^{\circ} \mathrm{C}$ (the actual temperature at Lac Lili) and only five lakes between 15 and $16^{\circ} \mathrm{C}$, and (4) the training set function is perhaps inappropriate for shallow lakes. Shallow-water taxa tend to have warmer-than-today temperature optima (Korhola et al. 2002). Thus. it is not surprising that inferences were generally too warm. Lacking a cool hypolimnion, the lake can only support taxa that prefer warmer conditions. This could explain why colder-than-today percentages were always low (average of 32\%) in Lac Lili. The training set mainly comprises lakes with water depths greater than $5 \mathrm{~m}$. To increase the accuracy of the chironomid inferences, a larger number of shallow lakes should be added, or preferably, a new transfer function, composed only of shallow lakes. could be developed. Absence of modern analogues in eight samples and poor analogues in 85 samples suggest that fossil samples were dissimilar to the training set, possibly because of the high percentages of littoral taxa in the fossil assemblages. This situation was also observed in a shallow lake used for reconstructing climate in western Canada (Upiter et al. 2014), and the authors concluded that although the pattern of temperature changes was similar to those of the studied region, all inferences were within the error of the model and thus should be viewed with caution. The training set used in this study also possesses few lakes with 
mean-August temperatures similar to Lac Lili, and no lakes between $16.8^{\circ} \mathrm{C}$ and $18.9^{\circ} \mathrm{C}$. Inferences above $15^{\circ} \mathrm{C}$ are thus generally under-estimated (Electronic Supplementary Material Fig. 1). More lakes with mean-August temperatures above $15^{\circ} \mathrm{C}$ should be sampled to improve the accuracy of the model.

\section{Conclusions}

It has been shown that shallow lakes are impacted by climate change and temperature reconstructions from chironomids, along with other variables in sediments such as diatoms, zooplankton, and pollen, could help decipher the effects that temperature had on lake communities throughout the Holocene. Lac Lili provided an opportunity to determine if shallow lakes could be used to obtain reasonable temperature inferences. which are typically derived from deeper lakes around the world. Our results showed that although chironomids were effective for reconstructing the general pattern of climate change, their ability to provide accurate inferences was compromised and most were above the climate normal. Better accuracy in shallow lakes could be attained if appropriate transfer functions were used; either by increasing the number of shallow lakes in an existing training set, or by developing a transfer function with data exclusively from shallow lakes. In our opinion, the first option is preferable, as lakes that are presently shallow might have been deeper in the past, and if no deep lakes are included in the transfer function, temperature might not be accurately reconstructed, as samples from such lake will have poor analogues. Furthermore, lakes with temperatures between 16 and $19^{\circ} \mathrm{C}$ should be added to the existing transfer function to increase temperature coverage within the overall range. 


\section{Acknowledgements}

This research was funded by the Natural Sciences and Engineering Research Council of Canada (NSERC), the Centre National de la Recherche Scientifique (France), the European IRSES NEWFORESTS program; the MITAC program, the Institut Universitaire de France and the Institut Écologie et Environnement through the GDRI "Forêts Froides". We thank the French University Institute for its support, the University of Montpellier and Aix-Marseille University. Our thanks to R. Julien, D. Gervais, B. Brossier and M. Girardin for their participation in fieldwork. We greatly appreciate the contribution of the Ministère des Forêts. de la Faune et des Parcs du Québec (MFFP), especially P. Grondin. 


\section{References}

Ali AA. Asselin H. Larouche AC. Bergeron Y. Carcaillet C. Richard PJH (2008) Changes in fire regime explain the Holocene rise and fall of Abies balsamea in the coniferous forests of western Quebec. Canada. Holocene 18:693-703

Ali AA. Carcaillet C. Bergeron Y (2009) Long-term fire frequency variability in the eastern Canadian boreal forest: the influences of climate vs. local factors. Glob Change Biol $15: 1230-1241$

Ali AA. Blarquez O. Girardin MP. Hély C. Tinquaut F. El Guellab A. Valsecchi V. Terrier A. Bremond L. Genries A. Gauthier S. Bergeron Y (2012) Control of the multimillennial wildfire size in boreal North America by spring climatic conditions. Proc Natl Acad Sci 109:20966-20970

Axford Y. Briner JP. Cooke CA. Francis DR. Michelutti N. Miller GH. Smol JP. Thomas EK. Wilson CR. Wolfe AP (2009) Recent changes in a remote Arctic lake are unique within the past 200.000 years. Proc Natl Acad Sci 106:18443-18446

Bajolle L. Larocque-Tobler I. Gandouin E. Lavoie M. Bergeron Y. Ali AA (2018) Major postglacial summer temperature changes in the central coniferous boreal forest of Quebec (Canada) inferred using chironomid assemblages. J Quat Sci 33:409-420

Bennett KD (1996) Determination of the Number of Zones in a Biostratigraphical Sequence. New Phytol 132:155-170

Blaauw M (2010) Methods and code for 'classical' age-modelling of radiocarbon sequences. Quat Geochronol 5:512-518 
Blindow I. Hargeby A. Andersson G (2002) Seasonal changes of mechanisms maintaining clear water in a shallow lake with abundant Chara vegetation. Aquat Bot 72:315-334

Blouin J. Berger J-P (2005) Guide de reconnaissance des types écologiques: région écologique 6a. Plaine du Lac Matagami: Région écologique 6b. Plaine de la Baie de Rupert. Ministère Ressour Nat Faune Dir Inven For Div Classif Écologique Product Stn

Borcard D. Gillet F. Legendre P (2011) Numerical Ecology with R. Springer New York

Brodersen KP. Lindegaard C (1997) Significance of subfossile chironomid remains in classification of shallow lakes. Hydrobiologia 342-343:125-132

Brodersen KP. Odgaard BV. Vestergaard O. Anderson NJ (2001) Chironomid stratigraphy in the shallow and eutrophic Lake Sobygaard. Denmark: chironomid-macrophyte cooccurrence. Freshw Biol 46:253-267

Brooks SJ. Birks HJB (2001) Chironomid-inferred air temperatures from Lateglacial and Holocene sites in north-west Europe: progress and problems. Quat Sci Rev 20:17231741

Brooks SJ. Langdon PG. Heiri O (2007) The identification and use of palaearctic chironomidae in palaeoecology. QRA Technical Guide No. 10. Quat Res Assoc London

Coops H. Beklioglu M. Crisman TL (2003) The role of water-level fluctuations in shallow lake ecosystems-workshop conclusions. Hydrobiologia 506:23-27

El-Guellab A. Asselin H. Gauthier S. Bergeron Y. Ali AA (2015) Holocene variations of wildfire occurrence as a guide for sustainable management of the northeastern Canadian boreal forest. For Ecosyst 2:1-7 
Engels S. Cwynar LC (2011) Changes in fossil chironomid remains along a depth gradient: evidence for common faunal thresholds within lakes. Hydrobiologia 665:15-38

Engels S. Cwynar LC. Rees ABH. Shuman BN (2012) Chironomid-based water depth reconstructions: an independent evaluation of site-specific and local inference models. J Paleolimnol 48:693-709

Environnement Canada (2017) Normales Climatiques au Canada. 1971-2000. Service Météorologique du Canada. Available on the internet: http://climate.weatheroffice.ec.gc.ca/ climate_normals/

Garralla S. Gajewski K (1992) Holocene vegetation history of the boreal forest near Chibougamau. central Quebec. Can J Bot 70:1364-1368

Glew JR (1991) Miniature gravity corer for recovering short sediment cores. J Paleolimnol $5: 285-287$

Greffard M-H. Saulnier-Talbot É. Gregory-Eaves I (2012) Sub-fossil chironomids are significant indicators of turbidity in shallow lakes of northeastern USA. J Paleolimnol $47: 561-581$

Grimm EC (1987) CONISS: a FORTRAN 77 program for stratigraphically constrained cluster analysis by the method of incremental sum of squares. Comput Geosci 13:13-35.

Heiri O. Cremer H. Engels S. Hoek WZ. Peeters W. Lotter AF (2007) Lateglacial summer temperatures in the Northwest European lowlands: a chironomid record from Hijkermeer. the Netherlands. Quat Sci Rev 26:2420-2437

Heiri O. Lotter AF (2010) How does taxonomic resolution affect chironomid-based temperature reconstruction? J Paleolimnol 44:589-601 
Hély C. Girardin MP. Ali AA. Carcaillet C. Brewer S. Bergeron Y (2010) Eastern boreal North American wildfire risk of the past 7000 years: A model-data comparison. Geophys Res Lett 37:L14709 (lett)

Hua Q. Barbetti M. Rakowski AZ (2013) Atmospheric radiocarbon for the period 1950-2010. Radiocarbon 55:2059-2072

Jeppesen E. Meerhoff M. Davidson TA. Trolle D. Søndergaard M. Lauridsen TL. Beklioglu M. Brucet S. Volta P. González-Bergonzoni I. Nielsen A (2014) Climate change impacts on lakes: an integrated ecological perspective based on a multi-faceted approach. with special focus on shallow lakes. J Limnol 73:84-107

Juggins S (2003) C2 Program. Univ Newcastle. UK

Juggins S. Juggins MS. RODBC E (2015) Package 'rioja'

Korhola A. Vasko K. Toivonen HT. Olander H (2002) Holocene temperature changes in northern Fennoscandia reconstructed from chironomids using Bayesian modelling. Quat Sci Rev 21:1841-1860

Langdon PG. Holmes N. Caseldine CJ (2008) Environmental controls on modern chironomid faunas from NW Iceland and implications for reconstructing climate change. J Paleolimnol 40:273-293

Langdon PG. Ruiz Z. Wynne S. Sayer CD. Davidson TA (2010) Ecological influences on larval chironomid communities in shallow lakes: implications for palaeolimnological interpretations. Freshw Biol 55:531-545 
Larocque I (2001) How many chironomid head capsules are enough? A statistical approach to determine sample size for palaeoclimatic reconstructions. Palaeogeogr Palaeoclimatol Palaeoecol 172:133-142

Larocque I. Grosjean M. Heiri O. Bigler C. Blass A (2009) Comparison between chironomidinferred July temperatures and meteorological data AD 1850-2001 from varved Lake Silvaplana. Switzerland. J Paleolimnol 41:329-342

Larocque I. Hall RI (2003) Chironomids as quantitative indicators of mean July air temperature: validation by comparison with century-long meteorological records from northern Sweden. J Paleolimnol 29:475-493

Larocque I. Pienitz R. Rolland N (2006) Factors influencing the distribution of chironomids in lakes distributed along a latitudinal gradient in northwestern Quebec. Canada. Can J Fish Aquat Sci 63:1286-1297

Larocque-Tobler I. Filipiak J. Tylmann W. Bonk A. Grosjean M (2016) Corrigendum to" Comparison between chironomid-inferred mean-August temperature from varved Lake Zabinskie (Poland) and instrumental data since 1896 AD"[Quat. Sci. Rev. 111 (2015) 35-50]. Quat Sci Rev 140:163-167

Learner MA. Wiles PR. Pickering JG (1989) The influence of aquatic macrophyte identity on the composition of the chironomid fauna in a former gravel pit in Berkshire. England. Aquat Insects 11:183-191

Luoto TP. Ojala AEK (2017) Meteorological validation of chironomids as a paleotemperature proxy using varved lake sediments. Holocene 27:870-878 
Meerhoff M. Jeppesen E (2009) Shallow Lakes and Ponds. In: Encyclopedia of Inland Waters. Elsevier. pp 645-655

Millet L. Rius D. Galop D. Heiri O. Brooks SJ (2012) Chironomid-based reconstruction of Lateglacial summer temperatures from the Ech palaeolake record (French western Pyrenees). Palaeogeogr Palaeoclimatol Palaeoecol 315:86-99.

Mooij WM. Janse JH. Domis LNDS. Hülsmann S. Ibelings BW (2007) Predicting the effect of climate change on temperate shallow lakes with the ecosystem model PCLake. Hydrobiologia 584:443-454

Overpeck JT. Webb T. Prentice IC (1985) Quantitative Interpretation of Fossil Pollen Spectra-Dissimilarity Coefficients and the Method of Modern Analogs. Quat Res 23:87-108

Price DT. Alfaro RI. Brown KJ. Flannigan MD. Fleming RA. Hogg E.. Girardin MP. Lakusta T. Johnston M. McKenney DW. Pedlar JH. Stratton T. Sturrock RN. Thompson ID. Trofymow JA. Venier LA (2013) Anticipating the consequences of climate change for Canada's boreal forest ecosystems. Environ Rev 21:322-365

R Core Team (2016) R: A Language and Environment for Statistical Computing. R Foundation for Statistical Computing. Vienna. Austria. http://www.R-project.org/

Reimer PJ. Bard E. Bayliss A. Beck JW. Blackwell PG. Ramsey CB. Buck CE. Cheng H. Edwards RL. Friedrich M. Grootes PM. Guilderson TP. Haflidason H. Hajdas I. Hatté C. Heaton TJ. Hoffmann DL. Hogg AG. Hughen KA. Kaiser KF. Kromer B. Manning SW. Niu M. Reimer RW. Richards DA. Scott EM. Southon JR. Staff RA. Turney CSM. van der Plicht J (2013) IntCal13 and Marine13 Radiocarbon Age Calibration Curves 0-50.000 Years cal BP. Radiocarbon 55:1869-1887 
Saucier J-P. Grondin P. Robitaille A. Gosselin J. Morneau C. Richard PJH. Brisson J. Sirois L. Leduc A. Morin H. Thiffault É. Gauthier S. Lavoie C. Payette S (2009) Écologie forestière. Chap 4 Man For Seconde Édition Ouvrage Collect Éditions MultiMondes Ordre Ing For Qué Qué 2:165-315

Scheffer M. van Nes EH (2007) Shallow lakes theory revisited: various alternative regimes driven by climate. nutrients. depth and lake size. Hydrobiologia 584:455-466.

Smol JP (2016) Arctic and Sub-Arctic shallow lakes in a multiple-stressor world: a paleoecological perspective. Hydrobiologia 778:253-272

Tarkowska-Kukuryk M. Kornijów R (2008) Influence of spatial distribution of submerged macrophytes on Chironomidae assemblages in shallow lakes. Pol J Ecol 56:569-579

Upiter LM. Vermaire JC. Patterson RT. et al (2014) Middle to late Holocene chironomidinferred July temperatures for the central Northwest Territories. Canada. J Paleolimnol $52: 11-26$

Viau AE. Gajewski K (2009) Reconstructing Millennial-Scale. Regional Paleoclimates of Boreal Canada during the Holocene. J Clim 22:316-330. doi: 10.1175/2008JCLI2342.1

Viau AE. Gajewski K. Sawada MC. Fines P (2006) Millennial-scale temperature variations in North America during the Holocene. J Geophys Res 111. D09102

Walker IR. Cwynar LC (2006) Midges and palaeotemperature reconstruction-the North American experience. Quat Sci Rev 25:1911-1925

Wetzel RG (2001) Limnology: Lake and River Ecosystems. 3rd ed. Elsevier. San Diego 
Zhang E. Chang J. Cao Y. Tang H. Langdon P. Shulmeister J. Wang R. Yang X. Shen J (2017) A chironomid-based mean July temperature inference model from the south-east margin of the Tibetan Plateau. China. Clim Past 13:185-199 
Table 1 Radiocarbon dates from terrestrial plant macroremains

\begin{tabular}{|c|c|c|c|c|}
\hline $\begin{array}{l}\text { Laboratory } \\
\text { code }\end{array}$ & $\begin{array}{l}\text { Depth } \\
(\mathrm{cm})\end{array}$ & ${ }^{14} \mathrm{C}$ age (yr BP) & $\begin{array}{l}\text { Calibrated }{ }^{14} \mathrm{C} \text { age ranges } \\
\text { (cal yr BP; } 2 \sigma \text {-range)* }\end{array}$ & Material dated \\
\hline \multirow[t]{2}{*}{ Beta-427033 } & $23-27$ & $410 \pm 30$ & $430-519(0.83)$ & Plant macroremains \\
\hline & & & $331-358(0.12)$ & Plant macroremains \\
\hline \multirow[t]{2}{*}{ Beta-427032 } & $48-50$ & $1150 \pm 30$ & 978-1145 (0.90) & Plant macroremains \\
\hline & & & $1158-1170(0.05)$ & Plant macroremains \\
\hline \multirow[t]{2}{*}{ Beta-427031 } & $118-120$ & $2730 \pm 30$ & $2762-2876(0.95)$ & Plant macroremains \\
\hline & & & $2915-2915(0.01)$ & Plant macroremains \\
\hline Beta-427030 & $178-182$ & $3180 \pm 30$ & 3358-3453 (0.95) & Plant macroremains \\
\hline Beta-427029 & $228-232$ & $4780 \pm 30$ & $5468-5589(0.95)$ & Plant macroremains \\
\hline \multirow[t]{2}{*}{ Beta-427028 } & $278-282$ & $6150 \pm 30$ & $6966-7159(0.94)$ & Plant macroremains \\
\hline & & & $6960-6963(0.01)$ & Plant macroremains \\
\hline \multirow[t]{2}{*}{ Beta-427027 } & $304-306$ & $7670 \pm 30$ & $8407-8522(0.90)$ & Plant macroremains \\
\hline & & & $8528-8538(0.05)$ & Plant macroremains \\
\hline
\end{tabular}

*Calibrated ages: the means of the $2 \sigma$-ranges with highest probabilities (bold). 
Table 2 Occurrence and maximum percentages of taxa in the sediment of Lac Lili (total of 116 samples). littoral and eutrophic taxa (Brooks et al. 2007). temperature optima yielded by WA from the East Canadian transfer function (Larocque 2008. modified). and temperature categories in relation to optima.

\begin{tabular}{|c|c|c|c|c|c|c|c|c|}
\hline \multirow[b]{2}{*}{ Taxa identified in sediment core } & \multirow[b]{2}{*}{ Occurrence } & \multirow[b]{2}{*}{$\begin{array}{c}\text { Maximum } \\
\text { percentages }\end{array}$} & \multirow[b]{2}{*}{$\begin{array}{c}\text { Not } \\
\text { included } \\
\text { in Fig. } 3\end{array}$} & \multirow[b]{2}{*}{$\underset{\text { taxa }}{\text { Littoral }}$} & \multirow[b]{2}{*}{$\begin{array}{l}\text { Eutrophic } \\
\text { taxa }\end{array}$} & \multirow{2}{*}{$\begin{array}{c}\text { Optima } \\
\text { East Canadian }\end{array}$} & \multicolumn{2}{|c|}{ Category } \\
\hline & & & & & & & $\begin{array}{l}\text { Colder } \\
\text { than } \\
\text { today } \\
\left(13.6^{\circ} \mathrm{C}\right)\end{array}$ & $\begin{array}{c}\text { Warmer } \\
\text { than } \\
\text { today } \\
\left(13.6^{\circ} \mathrm{C}\right)\end{array}$ \\
\hline Ablabesmyia spp. & 110 & 12.8 & & & & 14.2 & & $\mathrm{X}$ \\
\hline Allopsectrocladius spp. & 44 & 6.9 & & $\mathrm{X}$ & & 15.8 & & $\mathrm{X}$ \\
\hline Chironomus anthracinus-type & 82 & 6.1 & & & $\mathrm{X}$ & 12.2 & $\mathrm{X}$ & \\
\hline Chironomus plumosus-type & 63 & 6.0 & & & $\mathrm{X}$ & 14.8 & & $\mathrm{X}$ \\
\hline Cladopelma lateralis-type & 70 & 8.3 & & $\mathrm{X}$ & & 13.6 & & \\
\hline Cladotanytarsus mancus-type-1 & 115 & 25.7 & & $\mathrm{X}$ & $\mathrm{X}$ & 12.2 & $\mathrm{X}$ & \\
\hline Corynoneura spp. & 58 & 7.5 & & & & 10.4 & $\mathrm{X}$ & \\
\hline Cricotopus spp. & 33 & 5.2 & & $\mathrm{X}$ & & 11.9 & $\mathrm{X}$ & \\
\hline Cryptochironomus spp. & 81 & 5.9 & & & & 14.9 & & $\mathrm{X}$ \\
\hline Dicrotendipes nervosus-type & 114 & 12.7 & & $\mathrm{X}$ & $\mathrm{X}$ & 14.5 & & $\mathrm{X}$ \\
\hline Einfeldia spp. & 4 & 1.0 & $\mathrm{X}$ & $\mathrm{X}$ & & 12.8 & $\mathrm{X}$ & \\
\hline Endochironomus albipennis-type & 11 & 2.8 & & $\mathrm{X}$ & $\mathrm{X}$ & 13.7 & & $\mathrm{X}$ \\
\hline Endochironomus impar-type & 8 & 1.9 & & $\mathrm{X}$ & $\mathrm{X}$ & 14.9 & & $\mathrm{X}$ \\
\hline Endochironomus tendens-type & 1 & 1.0 & $\mathrm{X}$ & $\mathrm{X}$ & $\mathrm{X}$ & 15.8 & & $\mathrm{X}$ \\
\hline $\begin{array}{l}\text { Gymnometriocnemus- } \\
\text { Bryophaenocladius spp. }\end{array}$ & 1 & 1.0 & $\mathrm{X}$ & & & not in model & & \\
\hline Glyptotendipes pallens-type & 47 & 5.0 & & $\mathrm{X}$ & $\mathrm{X}$ & 14.6 & & $\mathrm{X}$ \\
\hline Glyptotendipes severini-type & 15 & 1.1 & & $\mathrm{X}$ & $\mathrm{X}$ & 15.1 & & $\mathrm{X}$ \\
\hline Heterotrissocladius maeri-type & 1 & 1.1 & $\mathrm{X}$ & & & 9.6 & $\mathrm{X}$ & \\
\hline Hyporygma spp. & 2 & 1.0 & $\mathrm{X}$ & & & not in model & & \\
\hline Lauterborniella spp. & 115 & 16.5 & & $\mathrm{X}$ & $\mathrm{X}$ & 23.3 & & $\mathrm{X}$ \\
\hline Mesocricotopus spp. & 1 & 1.0 & $\mathrm{X}$ & & & 9.9 & $\mathrm{X}$ & \\
\hline Microtendipes pedellus-type & 75 & 10.3 & & $\mathrm{X}$ & & 13.5 & $\mathrm{X}$ & \\
\hline Nanocladius spp. & 2 & 1.0 & $\mathrm{X}$ & & & 12.5 & $\mathrm{X}$ & \\
\hline Omisus spp. & 1 & 1.0 & $\mathrm{X}$ & & & 15.2 & & $\mathrm{X}$ \\
\hline Orthocladinae spp. & 10 & 1.1 & & & & not in model & & \\
\hline Orthocladius spp. & 2 & 1.0 & $\mathrm{X}$ & & & 13.6 & & \\
\hline Pagastiella spp. & 34 & 3.8 & & $\mathrm{X}$ & & 14.5 & & $\mathrm{X}$ \\
\hline Parachironomus varus-type & 27 & 1.9 & & $\mathrm{X}$ & & 13.5 & $\mathrm{X}$ & \\
\hline Parakiefferiella spp. & 92 & 8.7 & & $\mathrm{X}$ & $\mathrm{X}$ & 10.7 & $\mathrm{X}$ & \\
\hline Paraphaenocladius spp. & 1 & 1.9 & $X$ & & & not in model & & \\
\hline Paratanytarsus spp. & 95 & 13.3 & & $\mathrm{X}$ & & 12.8 & $\mathrm{X}$ & \\
\hline Paratendipes nudisquama-type & 5 & 1.0 & $\mathrm{X}$ & $\mathrm{X}$ & & not in model & & \\
\hline Pentaneurini spp. & 16 & 1.9 & & & & 14.9 & & $\mathrm{X}$ \\
\hline Polypedilum nubifer-type & 116 & 23.2 & & $\mathrm{X}$ & $\mathrm{X}$ & 13.4 & $\mathrm{X}$ & \\
\hline Polypedilum nubeculosum-type & 10 & 2.1 & & $\mathrm{X}$ & $\mathrm{X}$ & 18.5 & & $\mathrm{X}$ \\
\hline Procladius spp. & 114 & 22.1 & & & $\mathrm{X}$ & 14.5 & & $\mathrm{X}$ \\
\hline
\end{tabular}




\begin{tabular}{|c|c|c|c|c|c|c|c|}
\hline Psectrocladius septentrionalis-type & 49 & 10.0 & & $\mathrm{X}$ & 12.2 & $\mathrm{X}$ & \\
\hline Psectrocladius sordidellus-type & 111 & 18.1 & & $\mathrm{X}$ & 12.4 & $\mathrm{X}$ & \\
\hline Pseudorthocladius spp. & 1 & 1.0 & $\mathrm{X}$ & & 22.6 & & $\mathrm{X}$ \\
\hline Sergentia coracina-type & 57 & 4.8 & & & 25.9 & & $\mathrm{X}$ \\
\hline Stempellina spp. & 72 & 7.9 & & & 15.8 & & $\mathrm{X}$ \\
\hline Stempelinella spp. & 43 & 6.5 & & & 14.6 & & $\mathrm{X}$ \\
\hline Stenochironomus spp. & 1 & 1.0 & $\mathrm{X}$ & & not in model & & \\
\hline Stictochironomus spp. & 2 & 1.0 & $\mathrm{X}$ & & 7.9 & $\mathrm{X}$ & \\
\hline Tanytarsus spp. & 110 & 15.6 & & $\mathrm{X}$ & 12.6 & $\mathrm{X}$ & \\
\hline Tanytarsus chinyensis-type & 8 & 1.9 & & $\mathrm{X}$ & 15.1 & & $\mathrm{X}$ \\
\hline Tanytarsus glabrescens-type & 114 & 29.9 & & $\mathrm{X}$ & 15.6 & & $\mathrm{X}$ \\
\hline Tanytarsus lugens-type & 14 & 2.1 & & & 13.6 & & \\
\hline Tanytarsus mendax-type & 116 & 21.4 & & $\mathrm{X}$ & 14.1 & & $\mathrm{X}$ \\
\hline Tanytarsus pallidicornis-type & 116 & 24.3 & & $\mathrm{X}$ & 13.9 & & $\mathrm{X}$ \\
\hline Tanytarsus with spur on antenna & 21 & 3.9 & & $\mathrm{X}$ & 15.2 & & $\mathrm{X}$ \\
\hline Thiennemaniella spp. & 13 & 1.9 & & & not in model & & \\
\hline Thiennemanyia spp. & 10 & 3.1 & & & 12 & $\mathrm{X}$ & \\
\hline Zalutschia mucronata-type & 1 & 0.9 & $\mathrm{X}$ & & 13 & $\mathrm{X}$ & \\
\hline Zalutschia zalutschicola-type & 4 & 1.1 & $\mathrm{X}$ & & 14.7 & & $\mathrm{X}$ \\
\hline $\begin{array}{l}\text { Number of taxa not included } \\
\text { in the training set }\end{array}$ & & & & & 7 & & \\
\hline Maximum temperature $\left({ }^{\circ} \mathbf{C}\right)$ & & & & & 25.9 & & \\
\hline Minimum temperature $\left({ }^{\circ} \mathbf{C}\right)$ & & & & & 7.9 & & \\
\hline
\end{tabular}




\section{Figure captions}

Fig. 1 Map of Quebec (Canada) showing the location of study sites and the bioclimatic domains

Fig. 2 Age-depth model and sediment accumulation rates for the Lac Lili core

Fig. 3 Chironomid stratigraphy of Lac Lili. Chironomid percentage changes for the taxa present in more than six samples, the number of head capsules per sample, percentage of littoral taxa (based on Brooks et al. 2007), percentage of eutrophic taxa (based on Brooks et al. 2007) and the percentage of colder-than-today taxa (based on the East Canadian temperature optima). PCA axis 1 and 2 are the scores of the principal component analysis made on the percentages of chironomid taxa with percentages $>1 \%$. Vertical lines displayed in the percentage of littoral taxa and the percentage of colder-than-today taxa are the Holocene average. The vertical lines in the PCA axis 1 and 2 scores are the 0 score. The horizontal lines represent four significant zones identified using CONISS and the broken stick method. The chironomid taxa are ordered by their temperature optima in the training set. The black arrow identifies the 27 taxa with temperature optima equal to or warmer than $13.6^{\circ} \mathrm{C}$

Fig. 4 a Temperature reconstruction using chironomids preserved in the sediment of Lac Lili. The black line is the temperature reconstruction and the grey dots are the sample-specific errors. The vertical dotted lines are the zones identified in the chironomid stratigraphy. The horizontal grey lines are the average inferred temperatures within the zones. The black squares identify the eight samples with no analogues. b Chironomid-inferred temperature anomaly $\left({ }^{\circ} \mathrm{C}\right)$ in relation to $15^{\circ} \mathrm{C}(1961-1990)$ and $15.4^{\circ} \mathrm{C}$ (1981-2010). Inferences colder than reference periods are illustrated by large circles. The horizontal dotted bars are the mean anomaly compared to 15 and $15.4^{\circ} \mathrm{C}$

Fig 5. Summary of changes in Lac Lili and Lac Aurélie 
Electronic Supplementary Material Fig. S1 Results of the transfer function. Upper panel: observed versus inferred temperatures of the lakes in the training set. Lower panel: Observed temperature versus residuals. Residuals are the differences between observed and reconstructed temperature. whereas the 1:1 shows the theoretical perfect correspondence between observed and inferred temperatures. From the 1:1 relationship, we can see which samples overestimate or underestimated the true temperature and from the residuals we can see by how much $\left({ }^{\circ} \mathrm{C}\right)$. Lakes warmer than $15^{\circ} \mathrm{C}$ were generally under-estimated and there were no lakes between 16.8 and $18.9^{\circ} \mathrm{C}$ 


\section{Figure}

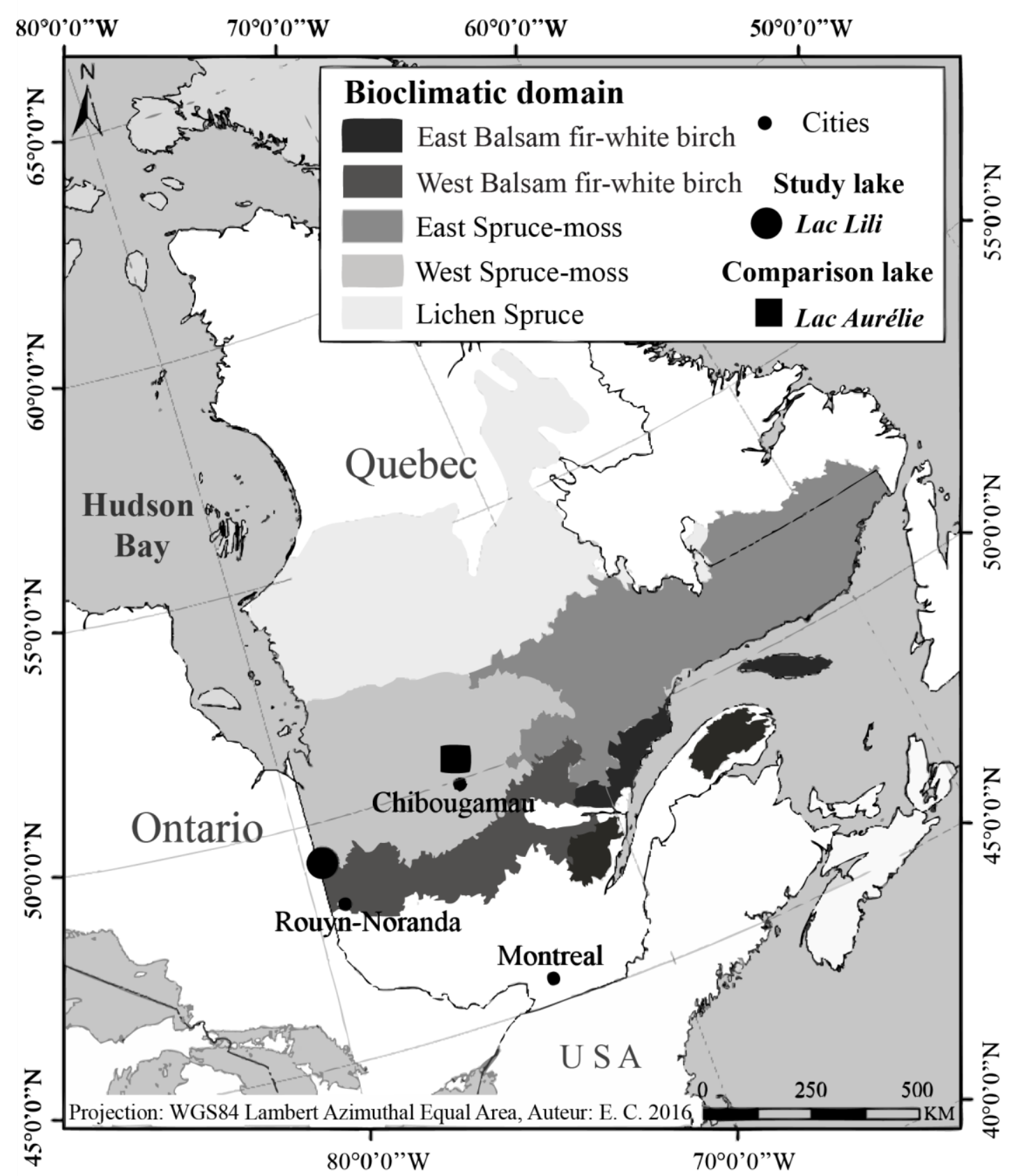

Fig. 1 


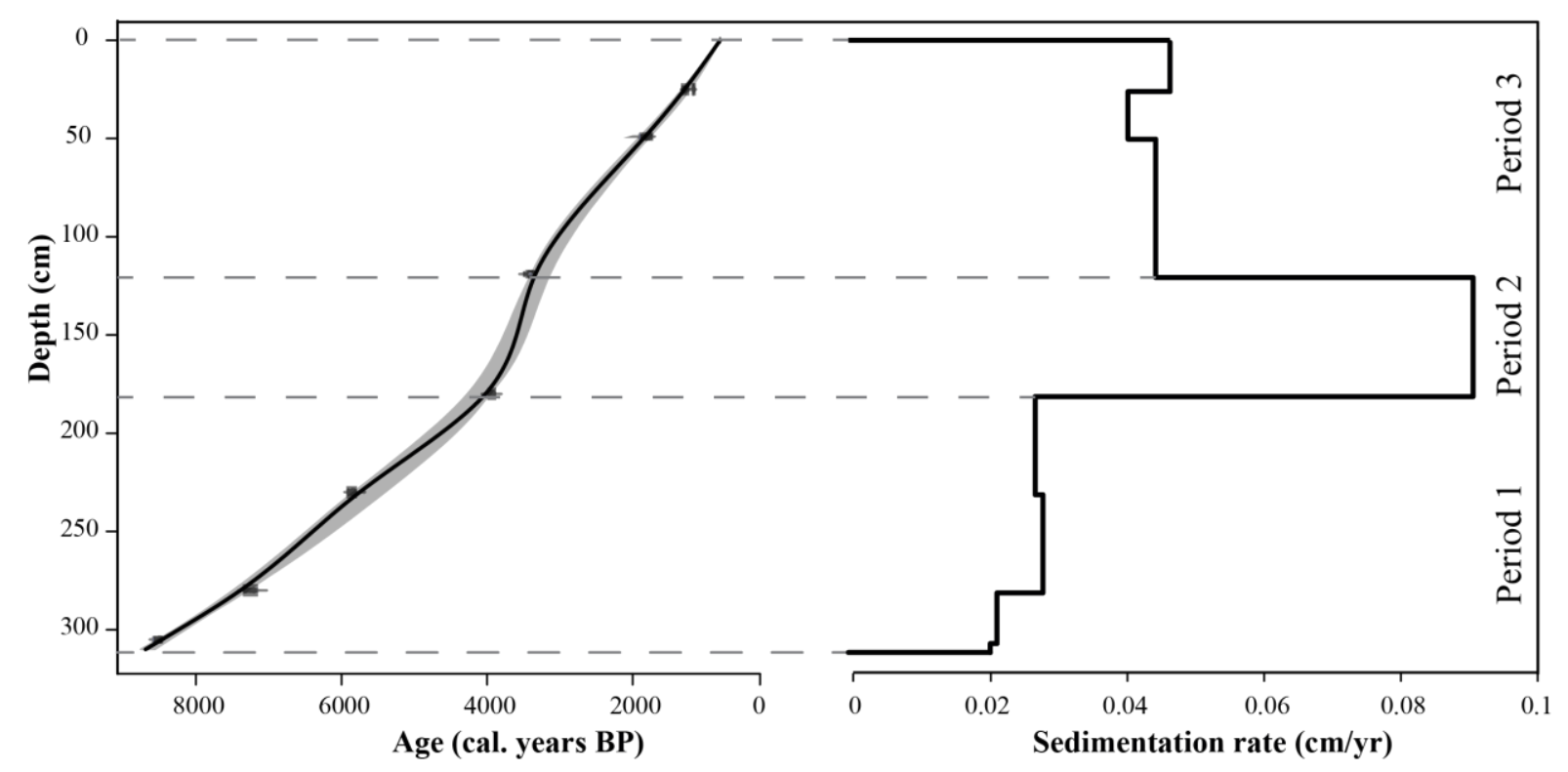

Fig. 2 


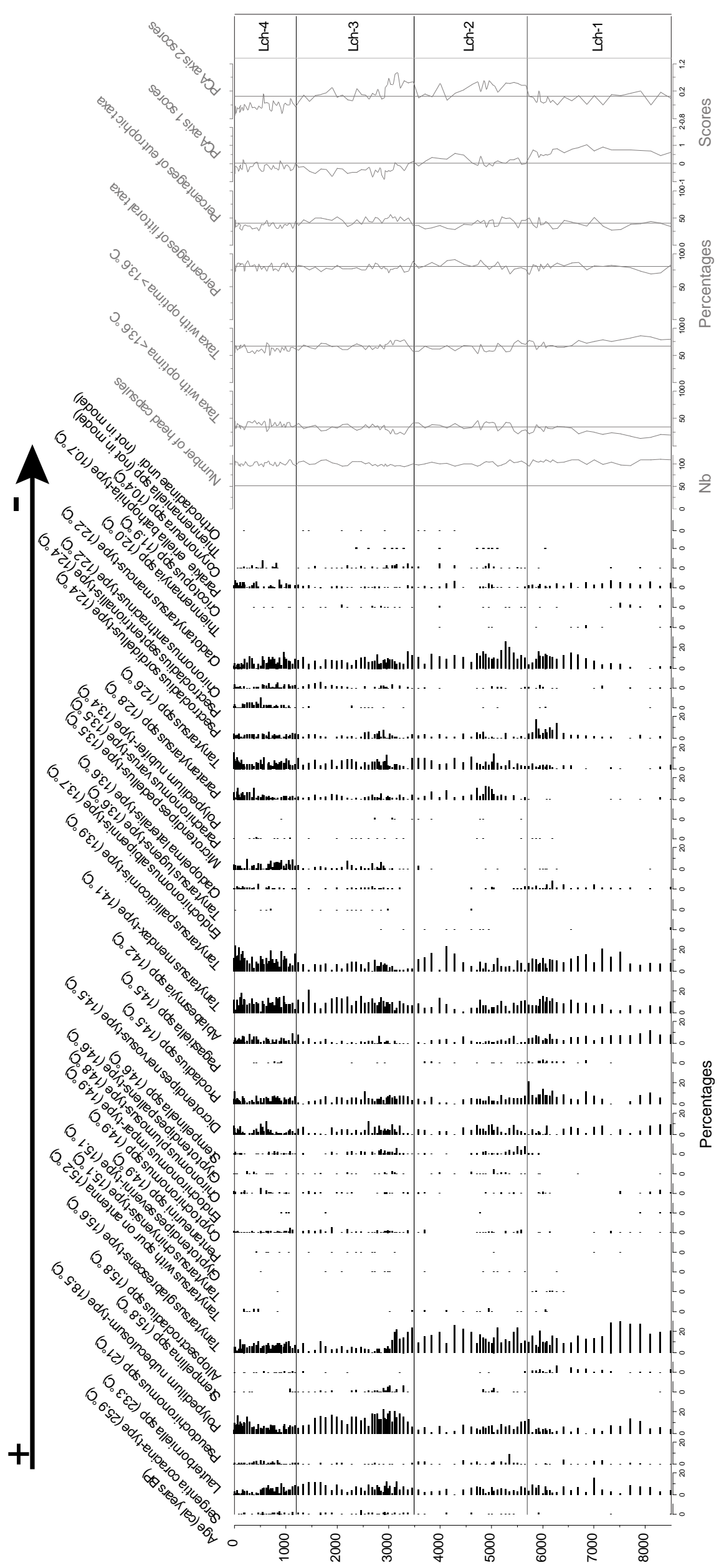




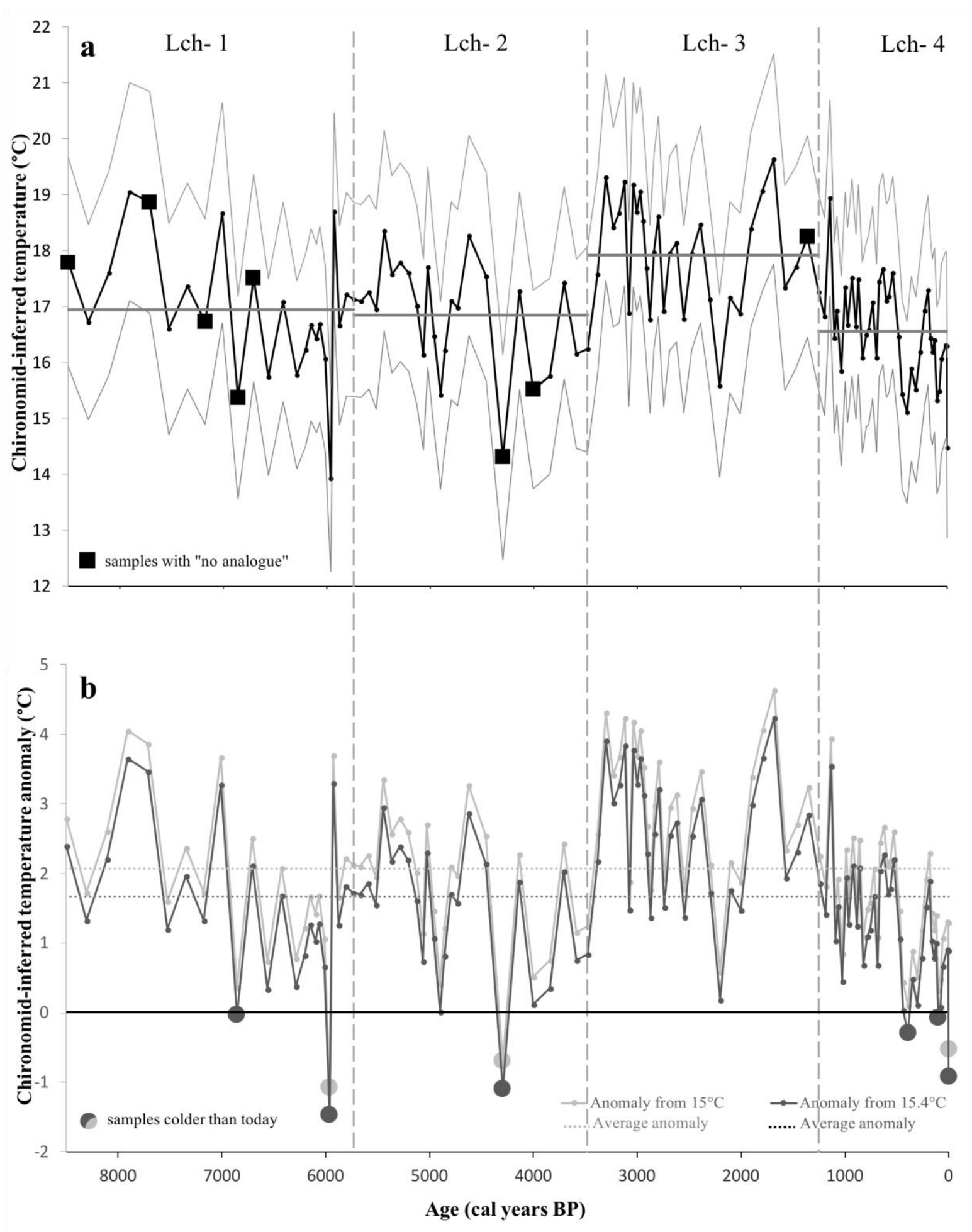

Fig. 4 


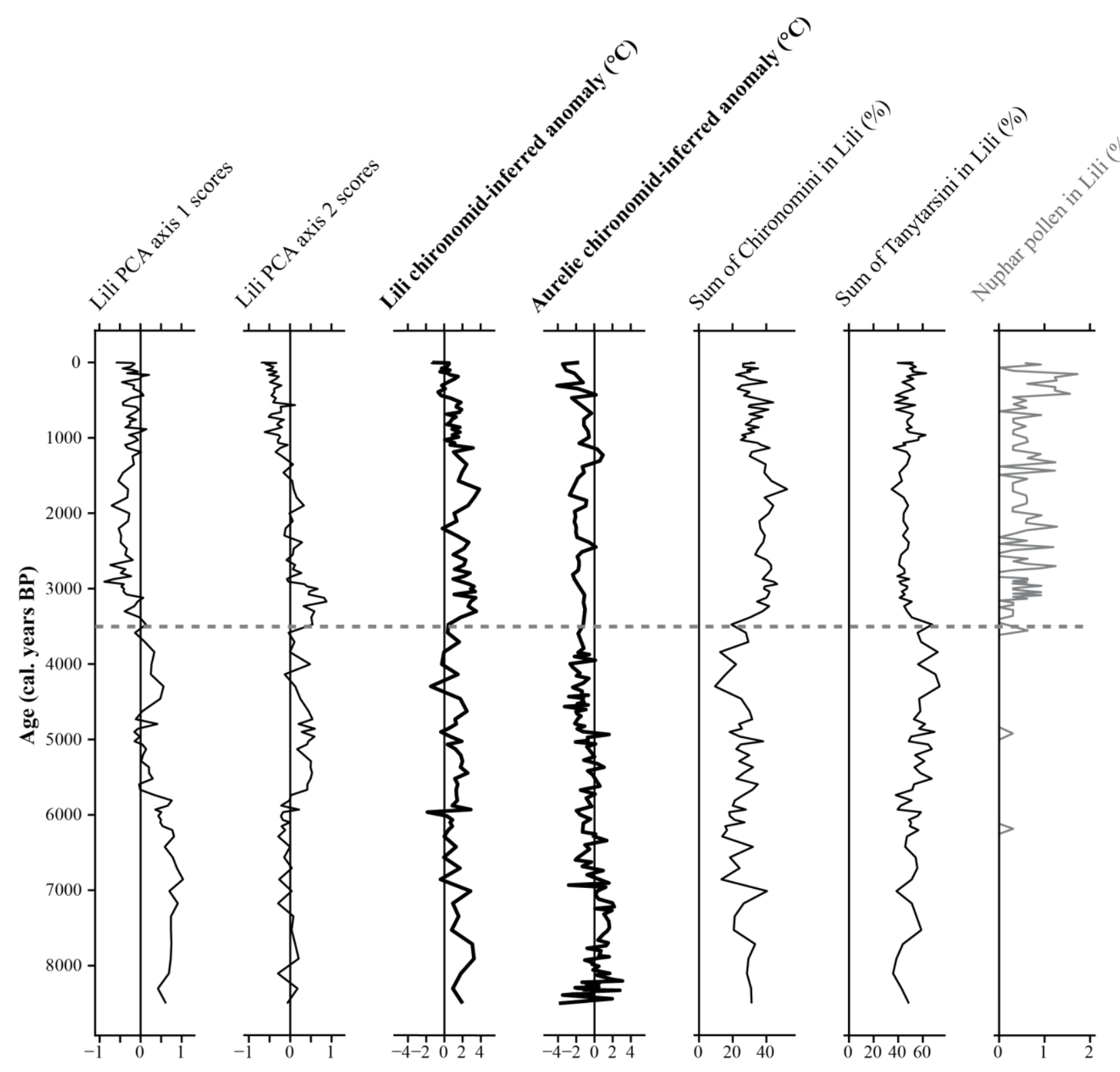

Fig. 4 

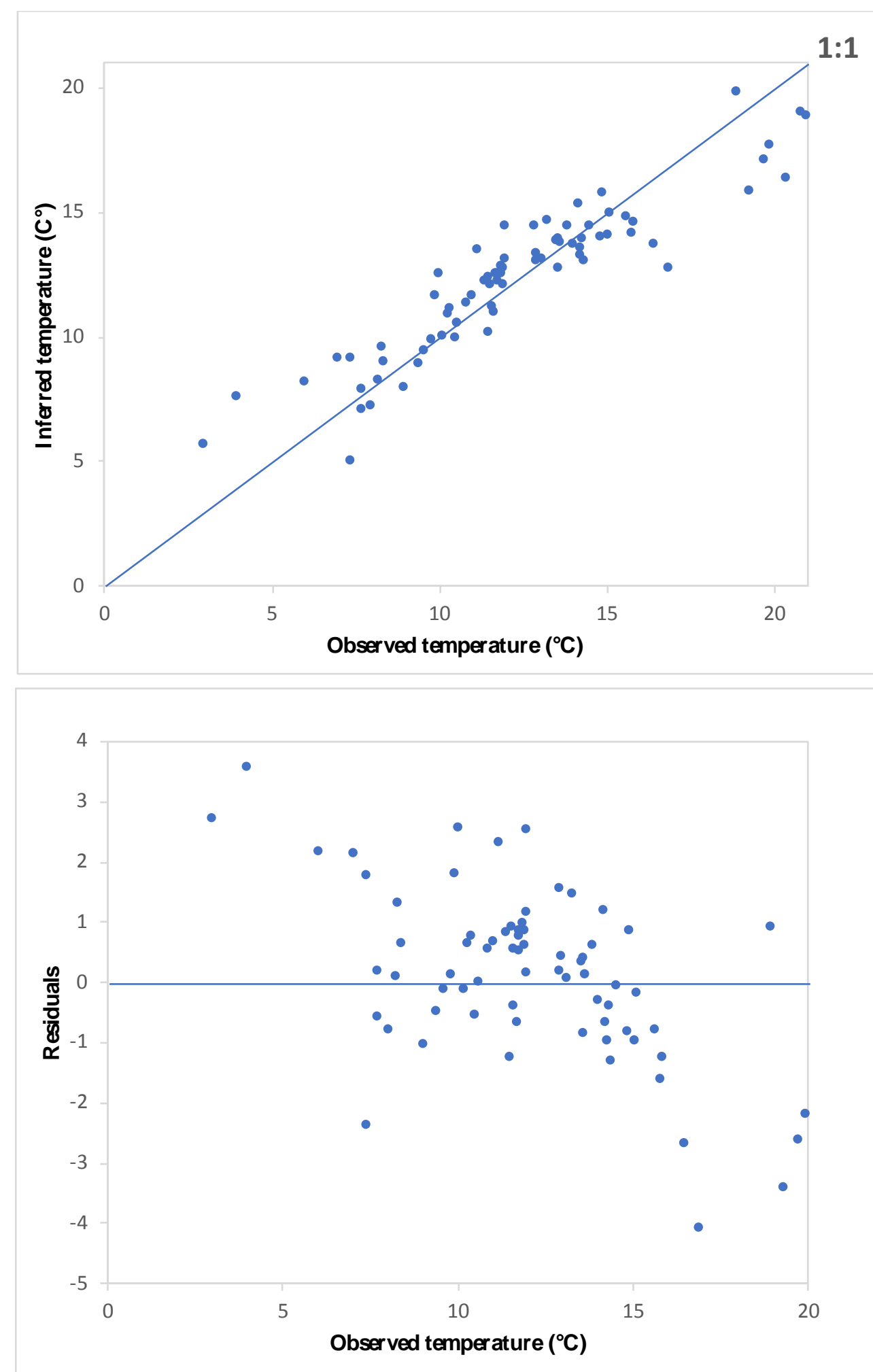

Fig. Supplementary data 1 